\title{
О ПРОДОЛЬНЫХ МЕЗОФОРМАХ СМЕШАННЫХ И ПЕСЧАНЫХ ПЛЯЖЕЙ
}

При исследовании динамики насосов отмелой береговой зоны Әстонского берегового района Балтийского моря нами изучались и временные гравийные и галечные валы на небольших смешанных и песчаных пляжах. Хотя строение и условия образования этих продольных мезоформ пляжей в общем известны (Зенкович, 1962; Леонтьев, 1961 и др.), наши наблюдения могут представить определенный интерес с точки зрения изучения литодинамики берега.

На типично развитых галечных береговых зонах Әстонии берег представляет собой хорошо выраженный береговой вал. На его внешнем (мористом) склоне прослеживаются небольшие временные продольные элементы мезорельефа пляжа в виде галечных валов. Обычно размер галек, из которых они состоят, тем мельче, чем ниже они расположены на пляже. Если последний сравнительно крутой, то временные галечные валы скучиваются на нем, более молодые из них частично перекрывают более древние и поэтому нередко они трудно отличимы друг от друга.

Временные продольные валы из более крупнозернистого материала, чем основные наносы пляжа, установлены и на смешанных пляжах. По своему происхождению они представляют собой аналоги временных галечных валов галечных пляжей. Их наличие установлено и в толще пляжевых песков (Зенкович, 1962). Осо-

бенностью временных валов смешанных пляжей, как отмечено уже В. П. Зенковичем, является их ра-

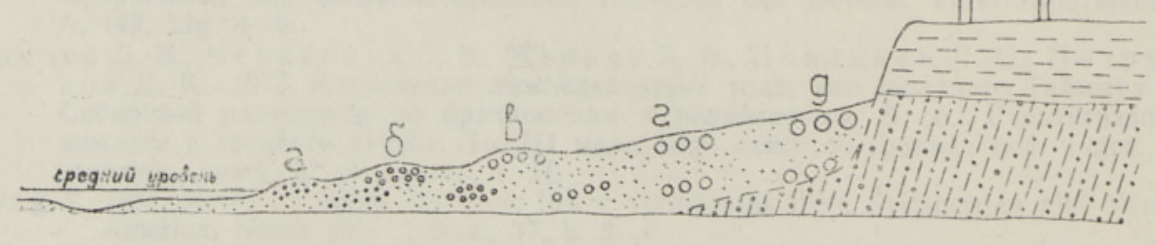

\section{VI:}

Рис. 1. Поперечный профиль берега смешанной береговой зоны:

1 - морена, 2 - древние прибрежные и дюнные пески, 3 - прибрежные пески современ-

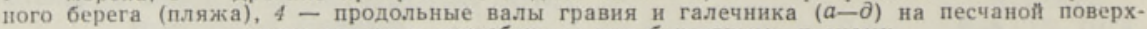
ности пляжа и погребенные под береговыми песками. 
зобщенность друг от друга более или менее широкими полосами песка. Временные валы характерны и для песчаных пляжей, хотя из-за мелкозернистости материала они выражены здесь менее отчетливо.
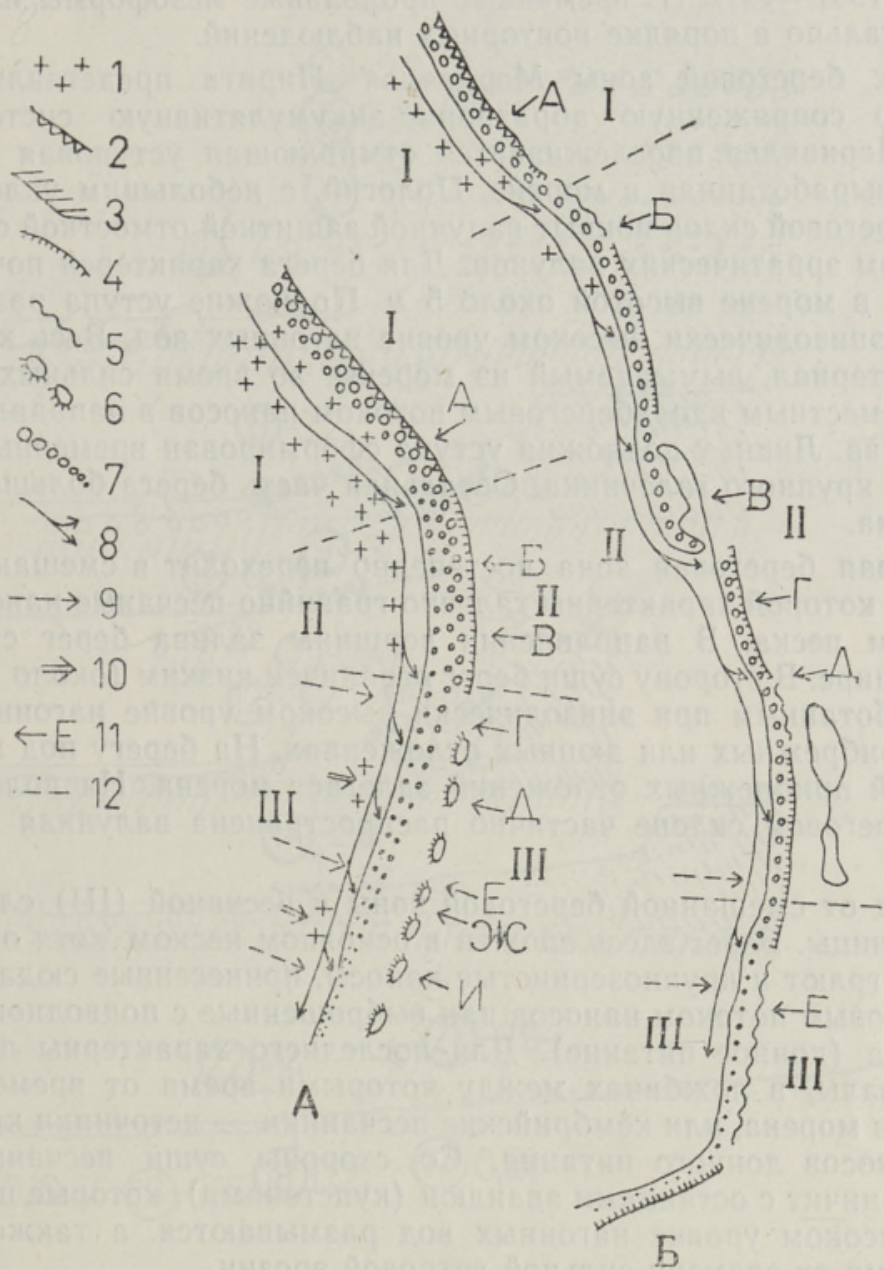

Рис. 2. Береговые зоны Меривялья-Пирита (А) и Лауласмаа-Клоога-Ранд (Б). Обозначения:

I - отмирающая уступовая береговая зона, II - смешанная береговая зона, III - песчаная береговая зона; 1 - эрратические валуны, 2 отмирающий береговой уступ, 3 - задернованная поверхность берега, 4 - эпизодически размываемые древние прибрежные пески, 5 - эпизодически размываемые авандюны, 6 - эпизолически размываемые останцы авандюн (купстены), 7 - валы крупнозернистых наносов на песчаной поверхности пляжа, 8 - местный вдольбереговой поток наносов, 9 - донное пнтание пляжа песчаными наносами, 10 - донное питание пляжа крупнозернистыми наносами, 11 - схематические поперечные профнли берега $(A-H:$ береговой участок Меривялья-Пирита; A-E: береговой участок Лауласмаа-Клоога-Ранд), откуда взять пробы для гранулометрических анализов (табл. 1, 2), 12 - границы подтнпов береговой зоны.

Разобщенное расположение временных валов крупнозернистых наносов на поверхности смешанных и песчаных пляжей, обусловленное, как известно, относительно пологой поверхностью последних, дает хорошую возможность для изучения строения и, в частности, изменения в процессе 
образования крупности наносов в зависимости от расположения их на пляже (рис. $1,4,5)$.

Проиллюстрируем это на примере двух участков береговой зоны Эстонского района - Меривялья-Пирита и Лауласмаа-Клоога-Ранд, где в течение 1967-1972 гг. временные продольные мезоформы пляжа изучались детально в порядке повторных наблюдений.

Участок беретовой зоны Меривялья-Пирита представляет собой небольшую сопряженную абразионно-аккумулятивную систему (рис. 2, А). В Меривялья прослеживается отмирающая уступовая береговая зона (I), выработанная в морене. Пологий, с неболышим уклоном подводный береговой склон покрыт валунной защитной отмосткой с большим количеством эрратических валунов. Для берега характерен почти заросший уступ в морене высотой около 5 м. Подножие уступа размывается лишь при эпизодически высоком уровне нагонных вод. Весь крупнозернистый материал, вымываемый из морены, во время сильных штормов выносится местным вдольбереговым потоком наносов в направлении вершины залива. Лишь у подножия уступа сформирован временный береговой вал из крупного галечника. Остальная часть берега большей частью задернована.

Уступовая береговая зона постепенно переходит в смешанную (II), для берега которой характерны галечно-гравийно-песчаные наносы с преобладанием песка. В направлении вершины залива берег становится положе и шире. В сторону суши берег ограничен низким (около 1 м) уступом, выработанным при эпизодически высоком уровне нагонных вод в древних прибрежных или дюнных отложениях. На берегу под маломощной толщей прибрежных отложений залегает морена. На пологом подводном береговом склоне частично распространена валунная защитная отмостка.

Переход от смешанной береговой зоны к песчаной (III) следует без четкой границы. Берег здесь сложен в основном песком, хотя определенную роль играют и крупнозернистые наносы, принесенные сюда местным вдольбереговым потоком наносов или выброшенные с подводного берегового склона (донное питание). Для последнего характерны подводные песчаные валы, в ложбинах между которыми время от времени обнажаются или морена, или кембрийские песчаники - источники крупнозернистых наносов донного питания. Со стороны суши песчаный берег (пляж) граничит с останцами авандюн (купстенами), которые при эпизодически высоком уровне нагонных вод размываются, а также подвергаются время от времени сильной ветровой эрозии.

\begin{tabular}{c|c|c}
\hline $\begin{array}{c}\text { Места отбо- } \\
\text { ра проб }\end{array}$ & $\begin{array}{c}\text { Мелкий } \\
\text { песок, \% }\end{array}$ & $\begin{array}{c}\text { Средний } \\
\text { песок, \% }\end{array}$ \\
\hline & & \\
Д & 52,7 & 36,8 \\
E & 64,6 & 18,8 \\
Ж & 75,6 & 18,8 \\
И & 86,0 & 12,6
\end{tabular}

В пределах аккумулятивной береговой зоны (рис. 2,A, II, III) основные наносы на берегу состоят из мелкозернистого песка. Анализы песков показали, что в семи пробах содержание мелкозернис того песка $(0,1-0,25$ мм) колеб. лется в пределах от 52,7 до $86,0 \%$, а содержание среднезернистого песка $(0,25-0,5$ мм) - от $12,6 \%$ до $36,8 \%$. В южной части рассматриваемого берегового участка наблюдается уменьшение количества среднезернистого и увеличение мелкозернистого песка в направлении вершины залива (рис. 2, А), что обусловлено общим снижением интенсивности волнения в этом направленин.

На поверхности смешанного (II) и песчаного (III) пляжей прослеживаются на разных высотах, в зависимости от сохранности с большей 


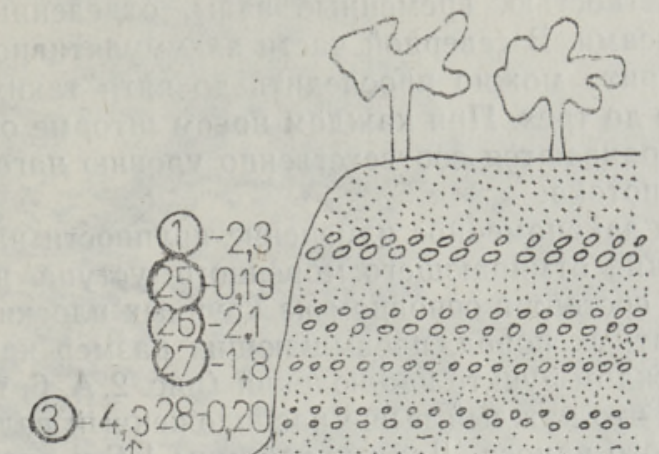

A

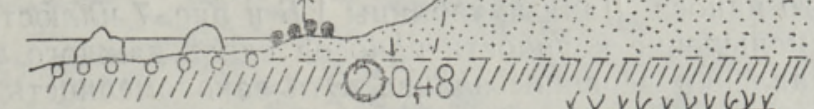

B

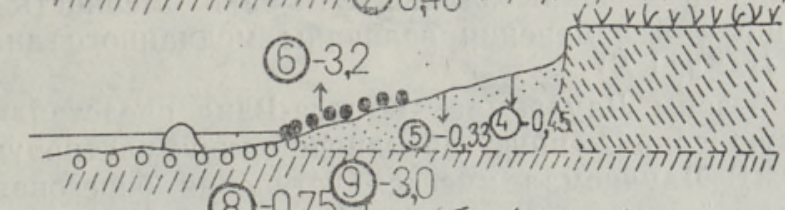

B

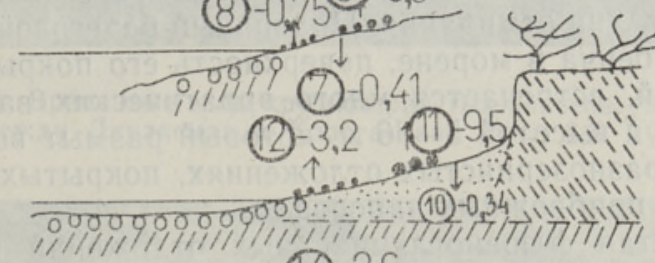

(14) $-2,6$

$\Delta$

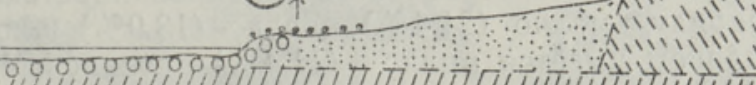

$-x 11111111111$
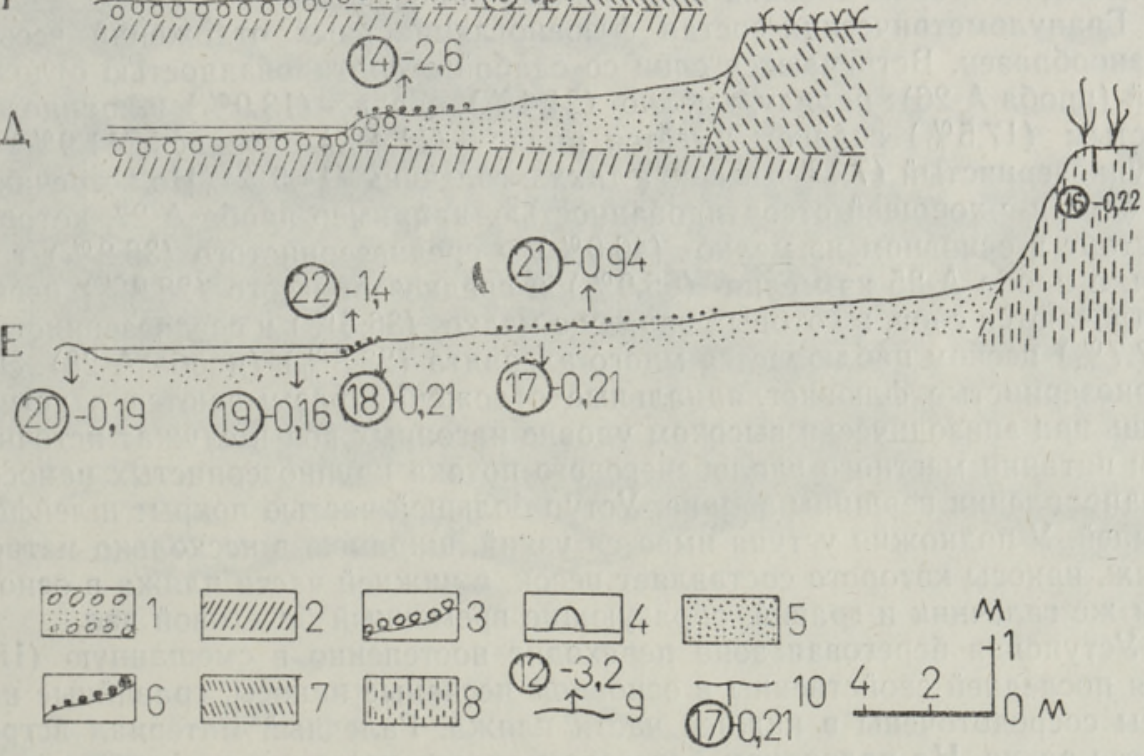

Рис. 3. Поперечные профили береговой зоны участка Лауласмаа-Клоота-Ранд. Места поперечных разрезов $A-E$ показаны на рис. 2,Б. Обозначения:

1 - слонстые разнозернистые флювногляциальные отложения, 2 - морена, 3 - защитная валунная отмостка, 4 - эрратические валуны, 5 - песок, 6 - валы крупнозернистых наносов на песчаной поверхности пляжа, 7 - древние прнбрежные пескн, 8 - дюнные пески,

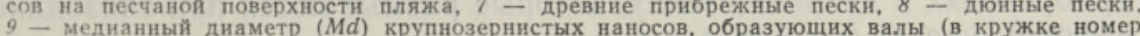
пробы), 10 - медианный диаметр песков с поверхности пляжа (в кружке номер пробы) (см. табл. 2). 
или меньшей четкостью, временные валы, отделенные друг от друга песчаными полосами. В северной части аккумулятивной береговой зоны Меривялья-Пирита можно проследить до пяти таких валов, в южной части - обычно до трех. При каждом новом шторме они полностью или частично перестраиваются соответственно уровню нагонных вод и энергии прибойного потока.

Наблюдается закономерное изменение крупности наносов временных валов. У подножия отмирающего моренного уступа нанос временного берегового вала состоит в основном из крупных плоских обломков ордовикских карбонатных пород, превышаюших размер крупного галечника (рис. $7, A)$. В каждом пункте наблюдений (рис. $2, \mathrm{~A}, 6$, табл. 1.A) хорошо прослеживается, что каждый выше расположенный вал состоит из более крупнообломочного наноса. Данные таблицы 1, 5 и рис. 7 иллюстрируют же постепенное уменышение крупности наносов вдоль каждого временного вала в направлении вершины залива. Эта закономерность проявляется также хорошо и в изменении величины медианного диаметра галек наносов вала (табл. $1, Б$ ).

Участок береговой зоны Лауласмаа-Клоога-Ранд представляет собой также небольшую сопряженную абразионно-аккумулятивную систему (рис. 2, Б и 3). В Лауласмаа имеется уступовая береговая зона (I) со следами начальной стадии отмирания. Подводный береговой склон пологий, выработан в виде бенча в морене, поверхность его покрыта валунной защитной отмосткой, встречается много эрратических валунов. Для берега характерен уступ высотой $5-6$ м, который размыт во флювиогляциальных слоистых разнозернистых отложениях, покрытых маломошным покровом древних прибрежных наносов.

Гранулометрический состав флювиогляциальных отложений весьма разнообразен. Встречаются слои со слабой отсортированностью отложений (проба А-26): наряду с мелко- $(21,4 \%)$, средне- $(13,9 \%)$ и крупнозернистым $(17,5 \%)$ гравием имеется мелко- $(11,4 \%)$, средне- $(11,9 \%)$ и крупнозернистый $(7,4 \%)$ песок, а также галечник $(14,5 \%)$. Но встречаются слои и с хорошей отсортированностью, например проба А-27. которая состоит в основном из мелко- $(46.0 \%)$ и среднезернистого $(36.2 \%)$ гравия, а проба А-25 из мелко- $(65,0 \%)$ и среднезернистого $(28,2 \%)$ песка. Встречаются слои, в которых наряду с мелко- $(36,5 \%)$ и среднезернистым $(17,7 \%)$ песком наблюдается много алеврита $(23,8 \%$ ) (проба А-28). Эти разнозернистые флювиогляциальные отложения размываются в уступе лишь при эпизодически высоком уровне нагонных вод и служат источником питания местного вдольберегового потока крупнозернистых наносов в направлении вершины залива. Уступ большей частью покрыт шлейфом осыпей. У подножия уступа имеется узкий, шириною в несколько метров пляж, наносы которого составляет песок, в нижней части пляжа в основном же галечник и гравий, образующие временный береговой вал.

Уступовая береговая зона переходит постепенно в смешанную (II). Для последней свойственны в основном песчаные наносы, гравийные наносы сосредоточены в нижней части пляжа. Галечный материал встречается редко. На подводном береговом склоне частично прослеживается еще бенч, выработанный на морене с валунной защитной отмосткой на последнем, в южном направлении появляются и подводные песчаные валы. В сторону суши берег ограничен низким (до 1 м) уступом в древних прибрежных и дюнных песках, которые размываются при эпизодически высоком уровне нагонных вод.

Переход в песчаную береговую зону (III) происходит плавно. Берег здесь сложен почти только мелкозернистым песком (от 63,4 до 96,1\%) с примесью среднезернистого песка (от 33,3 до 1,0\%). В небольшом коли- 


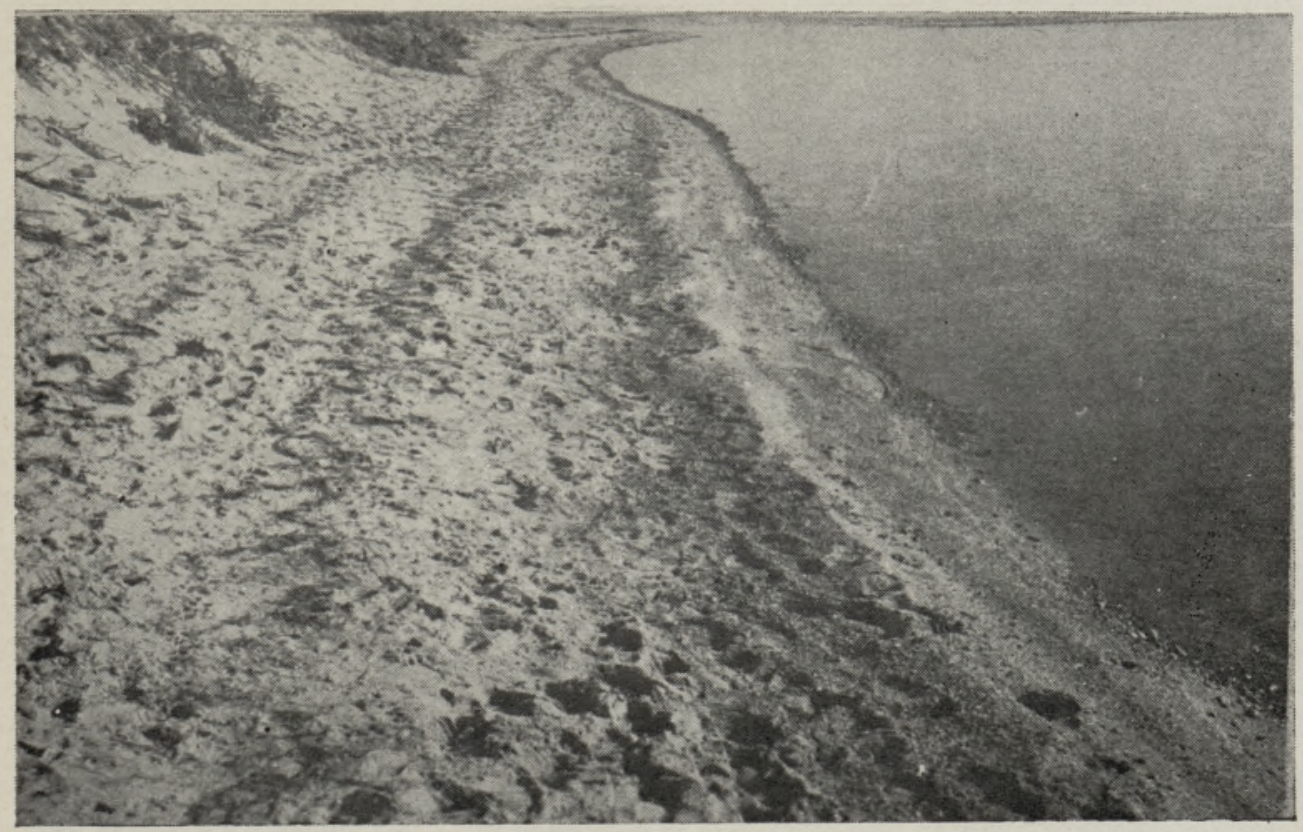

Рис. 4. Временные валы крупнозернистых наносов (темные) на песчаных наносах пляжа между Лауласмаа и Клоога-Ранд (рис. 2,Б и 3, профиль $Г$ ). Фото авторов.

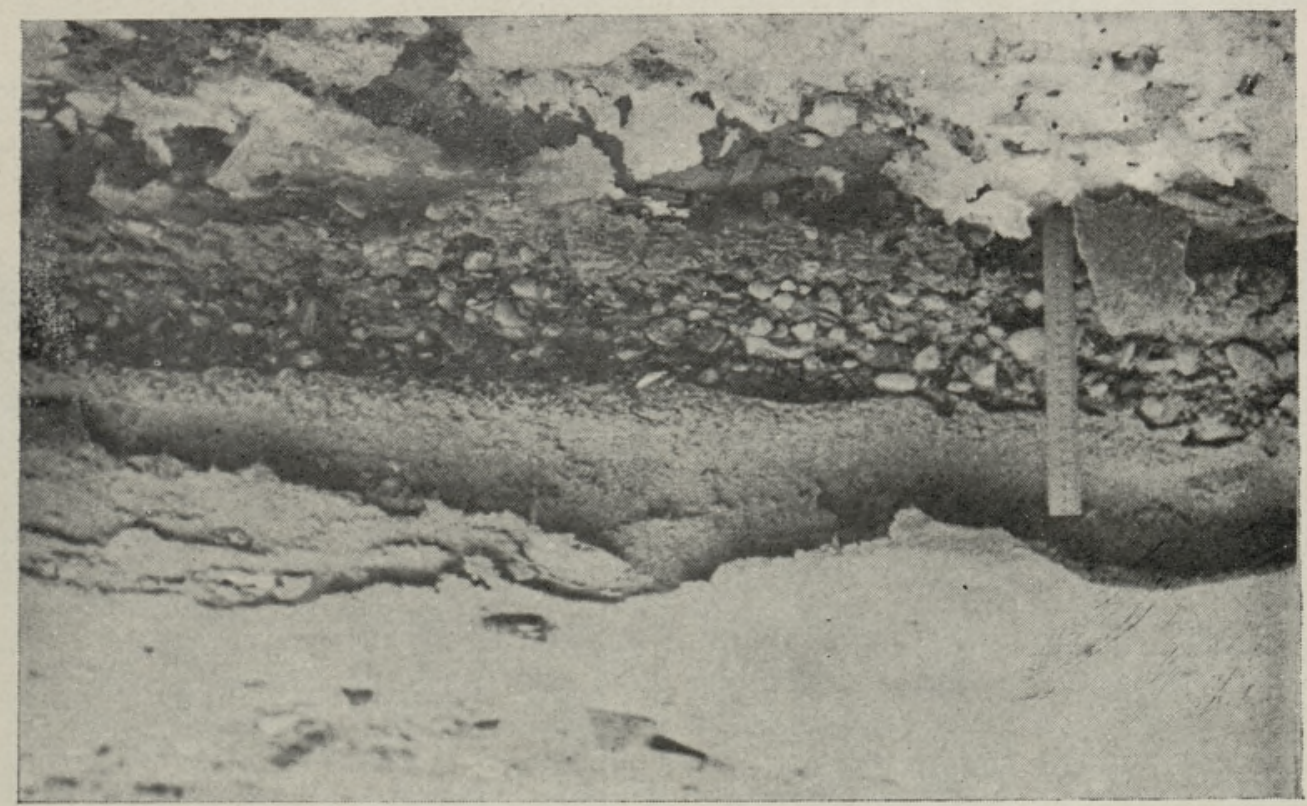

Рис. 5. Временный вал крупнозернистых наносов, погребенный под песчаными наносами пляжа между Меривялья и Пирита (рис, 2,А, профиль $B$ ). Фото авторов. 


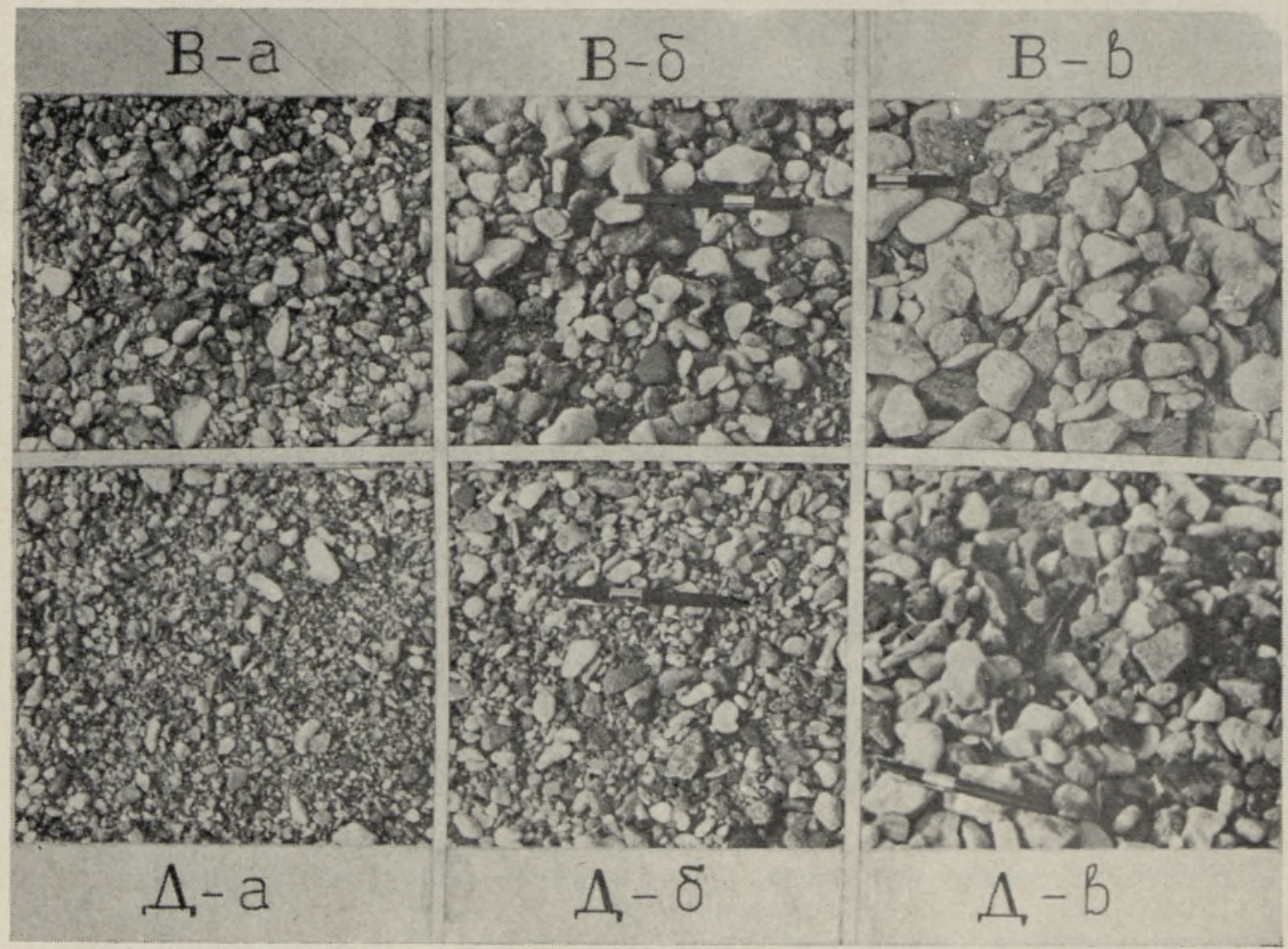

Рис. 6. Крупность наносов нижнего $(a)$, среднего (б) и верхнего $(в)$ вала крупнозернистых нано сов на поперечных профилях $B$ и $Ц$ пляжа между Меривялья и Пирита (см. рис. 2 А). В-а: $M d-$ 11 мм; В-б: $M d-37$ мм; В-в: $M d-66$ мм; Д-а: $M d-6,7 м м$ : Д-б: $M d-27$ мм; Д-в: $М d-$ 33 м... Уменьшение $6,5 \times$. Фото авторов.

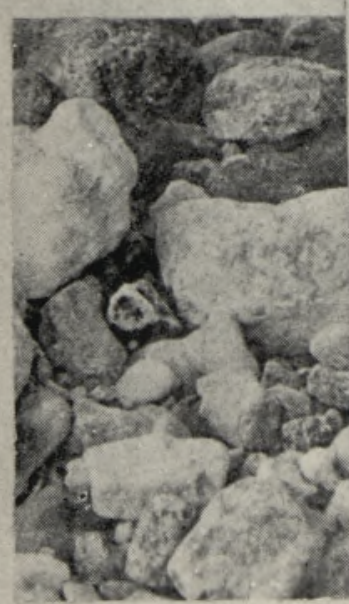

A

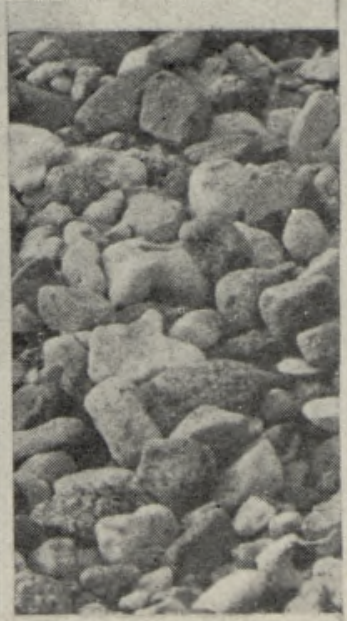

Б- $\delta$

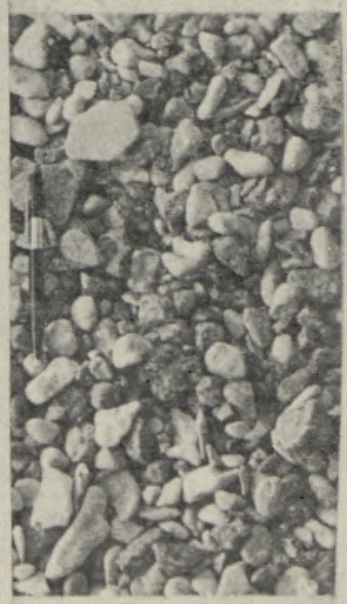

$\Gamma-\delta$

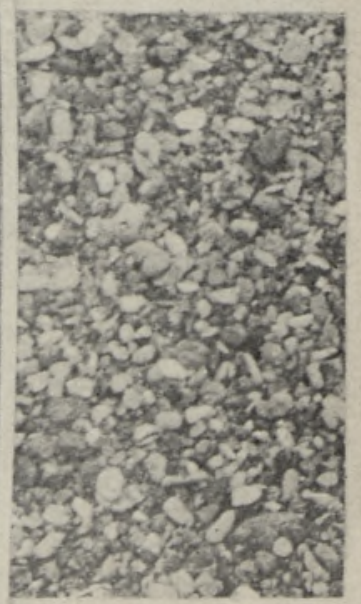

$n-\delta$

Рис. 7. Уменьшение крупности наносов среднего (б) вала крупнозернистых наносов в направлении вершины залива на поперечных профилях $Б, \Gamma, H$ пляжа между Меривялья и Пирита (см. рис. 2,A). Уменьшение $6,5 \times . A-$ крупность наносов временного вала у подножия отмирающего моренного уступа в Меривялья. Фото авторов. 
Таблица 1

Гранулометрический состав крупнозернистых наносов временных валов на песчаной поверхности пляжа береговой зоны Меривялья-Пирита (см. рис. 2,A, 6 и 7 ) $A$ - на поперечных профилях $B$ и Д; 5 - вдоль валов $a, 6,8$

\begin{tabular}{|c|c|c|c|c|c|c|c|c|c|c|c|}
\hline \multirow[b]{2}{*}{$\begin{array}{l}\text { Номер } \\
\text { пробы }\end{array}$} & \multirow[b]{2}{*}{$M d$} & \multicolumn{3}{|c|}{$\begin{array}{c}\text { Песок } \\
(0,1-1,0 \text { м. })\end{array}$} & \multicolumn{3}{|c|}{$\begin{array}{c}\text { Гравий } \\
(1,0-10,0 \text { мм })\end{array}$} & \multicolumn{3}{|c|}{$\begin{array}{c}\text { Галечник } \\
(10-100 \mathrm{M})\end{array}$} & \multirow[b]{2}{*}{ Валы } \\
\hline & & 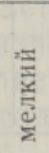 & 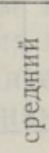 & 普 & $=$ & 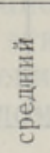 & 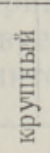 & & 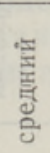 & $\begin{array}{l}\text { 产 } \\
\text { 吾 } \\
\text { 空 }\end{array}$ & \\
\hline
\end{tabular}

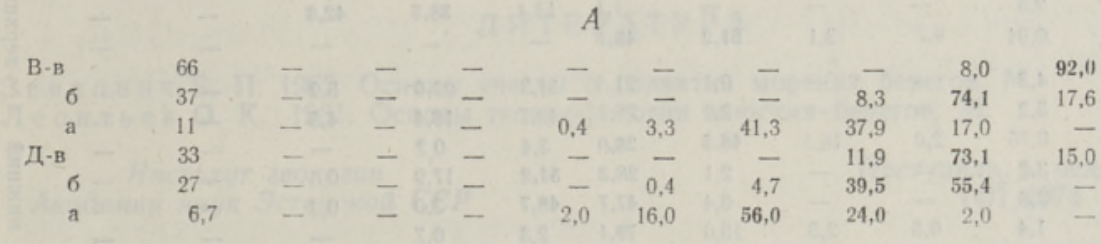

\section{Б}

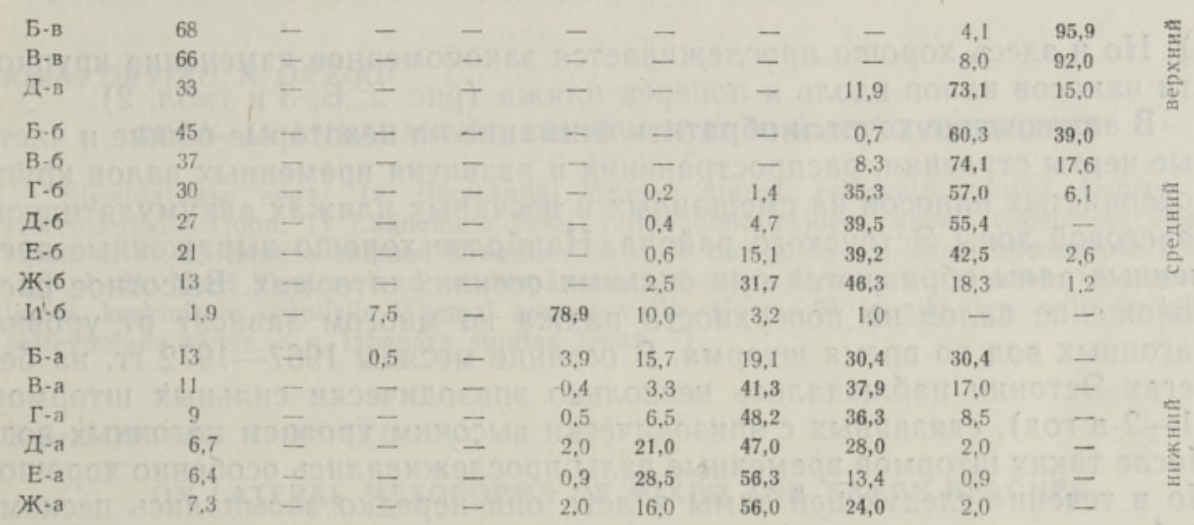

П ри м ч а ни и: набраниые полужирным шрнфтом цифры здесь и в табл, 2 соответствуют наиболее характерным фракциям.

честве встречаются и более крупные частицы - мелкозернистый гравий и крупнозернистый песок, образующиеедва прослеживаемые временные валы на поверхности пляжа. В присутствии этих крупнозернистых частиц можно убедиться после сильного выдувания песка с пляжа - тогда на поверхности последнего из них образуется или защитный покров, или эоловая рябь. На подводном береговом склоне сформировано несколько $(2-3)$ песчаных валов, из которых наиболее близкий к средней береговой линии во время низкого уровня сгонных вод осушается. Ширина осушки иногда достигает почти 100 м. Со стороны суши песчаный берег (пляж) граничит с авандюнами, которые при эпизодически высоком уровне нагонных вод могут подвергаться размыву.

Временных валов крупнозернистых наносов на поверхности смешанного и песчаного пляжей берегового участка Лауласмаа-Клоога-Ранд насчитывается не более трех, они меньше и менее четко выражены по сравнению с Меривялья-Пирита, крупность наносов в них меньше (рис. 
Таблица 2

Гранулометрический состав крупнозернистых наносов временных валов на песчаной поверхности пляжа береговой зоны Лауласмаа-Клоога-Ранд (см. рис. 2,Б и 3)

\begin{tabular}{|c|c|c|c|c|c|c|c|c|c|c|c|}
\hline \multirow{2}{*}{$\begin{array}{l}\text { Номер } \\
\text { пробы }\end{array}$} & \multirow{2}{*}{$M d$} & \multicolumn{3}{|c|}{$\begin{array}{c}\text { Песок } \\
(0,1-1,0 \text { м. })\end{array}$} & \multicolumn{3}{|c|}{$\begin{array}{c}\text { Гравий } \\
(1,0-10,0 \text { м. })\end{array}$} & \multicolumn{3}{|c|}{$\begin{array}{c}\text { Галечник } \\
(10-100 \text { м.м })\end{array}$} & \multirow[b]{2}{*}{ Валь } \\
\hline & & 莬 & $\begin{array}{l}\text { 高 } \\
\text { 至 } \\
\text { 号 }\end{array}$ & $\begin{array}{l}\text { 吾 } \\
\text { 至 } \\
\text { 至 }\end{array}$ & 吾 & $\begin{array}{l}\text { 至 } \\
\text { 总 } \\
\text { 品 }\end{array}$ & $\begin{array}{l}\text { 严 } \\
\text { 恶 } \\
\text { 点 }\end{array}$ & 焉 & $\begin{array}{l}\text { 恶 } \\
\text { 恶 } \\
\text { 号 } \\
0\end{array}$ & $\begin{array}{l}\text { 吾 } \\
\text { 至 } \\
\text { 员 } \\
\text { : }\end{array}$ & \\
\hline B-9 & 3,0 & - & 0,5 & 1,2 & 33,3 & 47,6 & 14,7 & 1,8 & - & - & 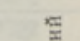 \\
\hline$\Gamma-11$ & 9,5 & - & - & - & 1,1 & 13,4 & 38,5 & 42,6 & - & - & $\bar{x}$ \\
\hline E-21 & 0,94 & 0,7 & 3,1 & 51,2 & 45,1 & - & - & - & - & - & 迨 \\
\hline A-3 & 4,3 & - & - & 0,1 & 21,5 & 51,3 & 22,0 & 5,2 & - & - & 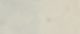 \\
\hline Б- 6 & 3,2 & - & - & 2.2 & 28,3 & 48,7 & 16,4 & 4,5 & - & - & \\
\hline B- 8 & 6.75 & 2,0 & 18,5 & 48,5 & 26,9 & 3,4 & 0,2 & - & - & - & 롶 \\
\hline$\Gamma-12$ & 3,2 & - & - & 2,1 & 28,3 & 51,2 & 17,9 & 0,5 & - & - & \# \\
\hline Д-14 & 2,6 & - & - & 0,4 & 47,7 & 48,7 & 3,0 & 0,2 & - & - & $\stackrel{2}{\equiv}$ \\
\hline E-22 & 1,4 & 0,5 & 2,3 & 15,0 & 79,1 & 2,3 & 0,7 & - & - & - & \\
\hline E-29 & 1,5 & - & - & 9,5 & 86,2 & 3,5 & 0,8 & - & - & - & \\
\hline
\end{tabular}

4). Но и здесь хорошо прослеживается закономерное изменение крупности наносов валов вдоль и поперек пляжа (рис. 2, Б, 3 и табл. 2).

В заключение хочется обратить внимание на некоторые общие и частные черты строения, распространения и развития временных валов крупнозернистых наносов на смешанных и песчаных пляжах аккумулятивной береговой зоны Эстонского района. Наиболее хорошо выраженные временные валы образуются при сильных осенних штормах. Высотное расположение валов на поверхности пляжа во многом зависит от уровня нагонных вод во время шторма. В осенние месяцы 1967-1972 гг. на берегах Эстонии наблюдалось несколько эпизодически сильных штормов (1-2 в год), связанных с эпизодически выссоким уровнем нагонных вод. После таких штормов временные валы прослеживались особенно хорошо. Но в течение следующей зимы и лета они нередко засыпались песком, выброшенным на пляж (в нижней части) или нанесенным ветром (в верхней части пляжа). Однажды погребенные валы могут либо сохраниться в толще наносов берега, образуя в последней линзы (в поперечном разрезе береговых наносов) крупнозернистых наносов среди песчаных (рис. 1 и 5), либо могут быть снова вымыты прибойным потоком или выдуты ветром. В последнем случае в пределах временного вала из наносов образуется защитная отмостка. В первом же случае временный вал может перестроиться в новый, несколько выше или ниже предыдущего. То же самое происходит с временными валами, оставшимися без покрова песка и снова попавшими под влияние деятельности прибойного потока. Крупнозернистый нанос накапливается на песчаной поверхности пляжа не всегда узким валом. Часто гальки разбросаны рассеянно на широкой полосе поверхности пляжа. Нередко временный вал перестраивается в цепь фестонов. Как рассеянные по поверхности пляжа галыки, так и фестоны могут быть также погребены в дальнейшем под песком и стать, таким образом, частью толши береговых отложений.

Нередко одновременно с накоплением временного вала крупнозернистых наносов в пределы последнего выбрасывается и морская трава, в частности фукусовые водоросли. Эти водоросли способствуют тому, что в следующее лето при наличии благоприятного волнового режима вдоль 
валов вырастает гряда травянистых растений, однако она уничтожается первым сильным осенним штормом.

Временные валы крупнозернистых наносов на песчаной поверхности пляжей смешанной и песчаной береговых зон отражают интенсивность и продолжительность воздействия волн при разных уровнях нагонных вод. Они свидетельствуют о сортировке пляжевых наносов по гидравлической крупности (Зенкович, 1962; Леонтьев, 1961). Нет сомнения, что изучение посредством повторных стационарных наблюдений процессов образования, развития и захоронения этих временных валов в пляжевые пески представляет интерес с точки зрения литодинамики пляжа, а также прибрежного осадконакопления в целом.

\section{ЛИТЕРА Т Р А}

З енк о вич В. П. 1962. Ооновы учения о развитии морских берегов. М. Л е онть в О. К. 1961. Основы геоморфолопни морских берегов. М.

Ннститут геологии

Академии наук Эстонской ССР
Поступила в редакщию 14/I 1974

\section{Kaarel ORVIKU, K. ORVIKU}

\section{SEGA- JA LIIVARANNAL ESINEVATEST PIKI-MESOVORMIDEST}

Kirieldatakse sega- ja liivaranna liivasel pinnal esinevaid ajutisi kruusa- ja veeristikuvalle (joon. 1) Läänemere Eesti rannavööndi-rajooni kahel väheldasel Iōigul (1oon. 2, 3). Esitatakse andmed kōnesolevaid valle moodustavate setete terasuuruse kohta (tab. 1, 2). Need illustreerivad seaduspärasust, et setete terasuurus väheneb igas madalamal, keskmisele veepiirile lähemal asuvas vallis (joon. 6) ja piki iga valli kohalike settevoolude rände, s. o. lahepära suunas (joon. 7).

\section{Kaarel ORVIKU, K. ORVIKU}

\section{ON LATERAL MESOFORMS OF MIXED AND SANDY BEACHES}

The authors present observation data on temporary lateral ridges (Зенкович, 1962: Леонтьев, 1961, and others) on small mixed and sandy beaches. The data were obtained in the course of a study of the dynamics of the shoaly emergent aggradational coastal zones of the Estonian region of the Baltic. Two sections of small, adjacent abrasionalaccumulative systems (Figs. 2 and 3 ) are described.

The temporary ridges on the sandy surface of both the mixed and sandy beaches consist of more coarse-grained deposits than the dominant deposits - sand - of those beaches. The ridges are separated from each other by stretches of the sandy cover of the beaches, of different widths. Owing to that fact, even the very low ridges are well traceable (Fig. 4). The ridges of more coarse-grained deposits, giving evidence of the accumulative activity of the swash of different intensity, in dependence of the differing level of storm surges, are constantly changing in shape. However, they are at times buried under the sand, and therefore conserved in the strata of beach deposits (Figs. 1 and 5).

Data are presented on the granulometric composition of the temporary shinglygravely ridges (Tables 1 and 2), illustrating a certain regularity in the decrease of the grain-size of the deposits in the downward direction of the beach slope (Fig. 6) and along every ridge, from the source of sediments in the direction of the transport of sediments by the local longshore drift of sediments. Concrete examples are described illustrating the movement of the sediments in the direction of bayhead (Fig. 7). 